\title{
猩紅熱の流行を起した T12型A群溶連菌に
}

\section{関する血清疫学的研究}

\section{一一特に， $\mathrm{T}$ 凝集素による血清疫学の試み一}

\author{
猩紅熱研究会（会長 中溝保三）
}

秋田衛研

$\begin{array}{lllll}\text { 森田 } & \text { 盛大 } & \text { 金鉄 } & \text { 三郎 } & \text { 高山 和子 } \\ \text { 藤宮 } & \text { 芳章 } & \text { 柴田 } & \text { 芳実 } & \end{array}$

白取㴊彦

須藤 恒 久

東北大医

石田名 香 雄

Key words: Scarlet fever, Group A streptococci type T12, Serum epidemiology

昭和48年10月上旬, 秋田県仙北郡角館町（人口 16,817 , 人口密度 $\left.106 / \mathrm{km}^{2}\right)$ にェリスロマイシン とテトラサイクリンに耐性の T 12 型 $\mathrm{A}$ 群溶連菌
（表 1 参照）による猩紅熱患者が 発生し，12月 までに図 1 亿示す如き発生パターンで猩紅熱が流 行した。罹患率（対人口10万）は 279.5であつた

Table 1 Drug Sensitivity of A Group Type 12 H.S. isolated from scarlet fever patients in Tsunodate town in 1973

\begin{tabular}{|c|c|c|c|c|c|}
\hline Drug & Conc. of Drug & $\begin{array}{l}\text { Isolation rate of } \\
\text { drug sensitive } \\
\text { Strain } \%\end{array}$ & Drug & Conc. of Drug & $\begin{array}{l}\text { Isolation rate of } \\
\text { drug sensitive } \\
\text { Strain } \%\end{array}$ \\
\hline \multirow{3}{*}{ Penicillin } & $0.5 \mathrm{u}$ & \multirow{3}{*}{100} & \multirow{3}{*}{ Sulfisoxazole } & $50 \mathrm{mcg}$ & \multirow{3}{*}{0} \\
\hline & $2 \mathrm{u}$ & & & $150 \prime \prime$ & \\
\hline & $10 \mathrm{u}$ & & & $300 "$ & \\
\hline \multirow{3}{*}{$\mathrm{AB}-\mathrm{PC}$} & $2 \mathrm{mcg}$ & \multirow{3}{*}{100} & \multirow{3}{*}{ Dihydro SM } & $2 \mathrm{mcg}$ & 71.4 \\
\hline & "I & & & $10 " \prime$ & \multirow{2}{*}{100} \\
\hline & $20 \quad \prime \prime$ & & & $50 \leqslant$ & \\
\hline \multirow{3}{*}{ E M } & $0.5 \mathrm{mcg}$ & \multirow{3}{*}{0} & \multirow{3}{*}{ Leucomycin } & $2 \mathrm{mcg}$ & \multirow{3}{*}{0} \\
\hline & $2 \quad \prime$ & & & $5 \prime \prime$ & \\
\hline & $10, " \prime$ & & & $15 \prime \prime$ & \\
\hline \multirow{3}{*}{ C P } & $5 \mathrm{mcg}$ & \multirow{2}{*}{0} & \multirow{3}{*}{ Colistin } & $50 u$ & \multirow{2}{*}{0} \\
\hline & $10 \quad " \prime$ & & & $100 " \prime$ & \\
\hline & 30 & 100 & & $300 "$ & 14.3 \\
\hline \multirow{3}{*}{ T C } & $5 \mathrm{mcg}$ & \multirow{2}{*}{0} & \multirow{3}{*}{$\mathrm{KM}$} & $5 \mathrm{mcg}$ & 71.4 \\
\hline & $10 \prime \prime$ & & & $10 " \prime$ & \multirow{2}{*}{100} \\
\hline & $30 " \prime$ & 14.3 & & $30 "$ & \\
\hline \multirow{3}{*}{ Oleandmycin } & $2 \mathrm{mcg}$ & \multirow{3}{*}{0} & & & \\
\hline & $10 " \prime$ & & & & \\
\hline & $15 \quad \prime \prime$ & & & & \\
\hline
\end{tabular}

Isolation rate of sensitive strains $=$ number of sensitive strains/number of tested strains $\times 100$, Number of tested Strains $=7$ 
Fig. 1 Incidence of scarlet fever cases in Tsunodate town by month and age (1973)
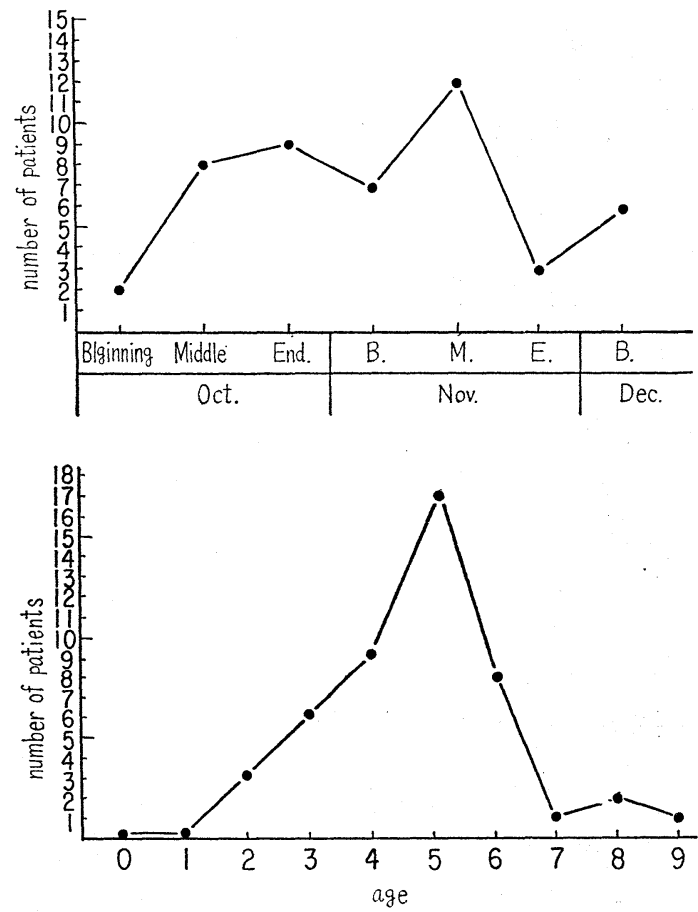

が，好発年令は $3 \sim 6$ 才で全体の $85 \%$ 占め，同 町 $3 \sim 6$ 才人口の $4.7 \%$ が猩紅熱に罹患した. 更 に，風疹などの発疹症と診断され，その後の細菌 学的, ウイルス学的及び血清学的検査で T 12 型菌 感染症と推定されたものも加えると同人口の 7.0 \%に達した。

本報では，本流行の中心となつた 2 幼稚園児を 対象に，主として T 12型凝集素を指標として行な つた血清疫学調查成績について報告する.

\section{材料と方法}

1. 被検血清

被検血清は流行開始後45日目の11月中旬及び流 行後の 2 月下旬（流行開始後 148日目）飞角館町 幼稚園児 114名及び角館保育園児 217名から採取 した血清，並びに，昭和46年 9 月のポリオ流行予 測調查時に同町一般健康住民 100 名から採取した 血清で，いずれも検査時迄一 $20^{\circ} \mathrm{C}$ に保存した。

2. A S O価測定

市販の A S Oの検查キットを用いてマイクロタ
表 2 マイクロタイター法による

T凝集素価測定法

A. $\mathrm{T}$ 凝集抗原

宮本らの方法 ${ }^{3)}$ で調製したトリプシン消化菌を O D $(550 \mathrm{~m} \mu) 0.35$ の濃度にしたものを T凝 集抗原とした。

B. 被検血清のA 群特異凝集素の吸収除去

1. 5 倍稀䣋被検血清 $0.5 \mathrm{ml}$ k $50 \%$ T 6 \& 25型 加熱菌液 $0.05 \mathrm{ml}$ を添加し擋拌.

2. $37^{\circ} \mathrm{C}, 60$ 分 $\rightarrow 4^{\circ} \mathrm{C}, 1$ 夜放置後遠心し, 上清 を採取。

C. T凝集素価測定一マイクロタイター法, Uプレ - r

1. $0.1 \%$ 牛血清アルブミン（B S A）加生食水 を稀釈液として $0.025 \mathrm{ml}$ ずつ分注.

2. B 項の被検血清 $0.025 \mathrm{ml}$ を 2 倍系列稀釈.

3. 稀䣋液を $0.025 \mathrm{ml}$ 追加.

4. $\mathrm{T}$ 凝集抗原を $0.05 \mathrm{ml}$ 添加後振蕰.

5. $37^{\circ} \mathrm{C}, 60$ 分 $\rightarrow 4{ }^{\circ} \mathrm{C}, 1$ 夜静置後, $75 \sim 100 \%$ 凝集像を示す最高血清稀釈倍数 $(\mathrm{C}-3$ 項) の逆数を以って T凝集素価とした.

イター法によつて測定した。

\section{T12型凝集価測定}

被検血清中の $\mathrm{A}$ 群特異 T凝集素を T 6 \& 25型 加熱菌で吸収除去した後, 別報 ${ }^{2)}$ 及び表 2 に示し た如く，OD0.35の濃度のトリプシン消化 T 12 型 菌を用いて T12型凝集素価をマイクロタイター法 によつて測定した。

\section{成 績}

1. A S O価分布の変動

流行前の昭和46年に採取した血清の年令別 A S O価は，図2 に示す如く，4-6才群より上昇 し，10一12才群にピークを有する分布パターンを 示した. 320 単位以上の A S O価を示したものは $6 \%$ にすぎなかつた。

これに対して，流行中期血清では，4〜6才児 に和けるAＳＯ価の上昇が認められ，特に，表 3 の A S O価分布に明らかな如く，320単位以上の 価を示したものが36.9\%に増加し，溶連菌感染 がこれらの小児間に流行にていることが示唆され た。しかし，流行後血清のA S O価分布（図 3 及 び表 3 ）は，流行中期に比較すると，分布パター ンが若干高值に移行する傾向を示したものの, 顕 著な変動は観察されなかつた。 
Fig. 2 ASO titer of Tsunodate town population in epidemic and non-epidemic period (Geometric mean)

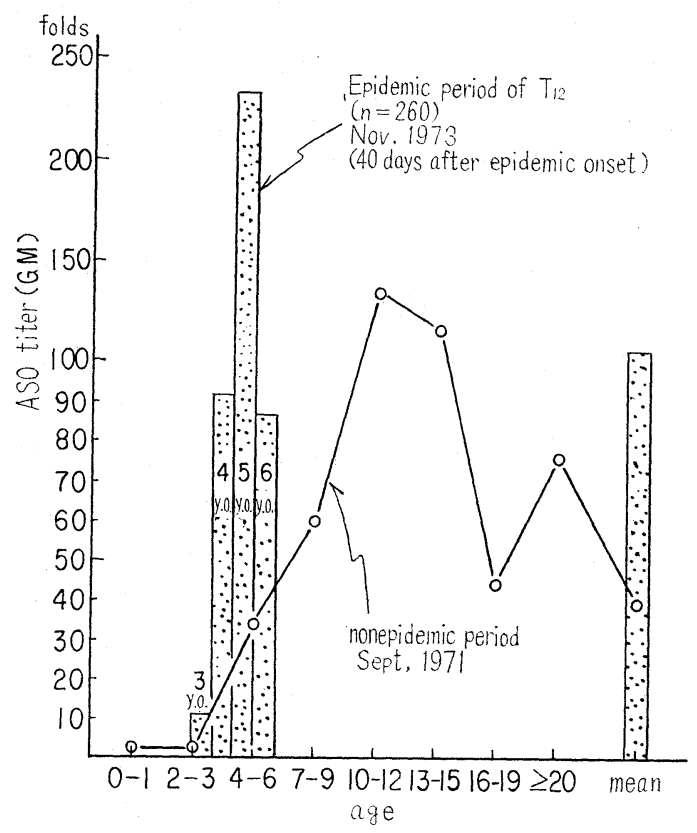

Table 3 ASO titer distribution rate $(\%)$ in middle and post epidemic period (Tsunodate town).

\begin{tabular}{|c|c|c|c|c|}
\hline \multicolumn{2}{|c|}{ ASO titer Institute } & $\begin{array}{l}\text { Tsunodate } \\
\text { Kinder- } \\
\text { garten }\end{array}$ & $\begin{array}{l}\text { Tsunodate } \\
\text { nursery } \\
\text { school }\end{array}$ & Total \\
\hline \multirow{6}{*}{ 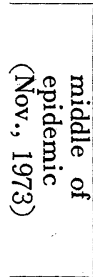 } & $\begin{array}{l}\text { Numb. of cases } \\
\text { tested }\end{array}$ & 88 & 172 & 260 \\
\hline & $\leq \times 20$ & 44.3 & 19.8 & 28.1 \\
\hline & $\times \quad 40 \sim 120$ & 15.9 & 23.2 & 20.8 \\
\hline & $\times 160 \sim 240$ & 12.5 & 15.1 & 14.2 \\
\hline & $\times 320 \sim 960$ & 18.2 & 36.1 & 30.0 \\
\hline & $\geq \times 1280$ & 9.1 & 5.8 & 6.9 \\
\hline \multirow{6}{*}{ 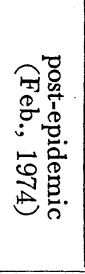 } & $\begin{array}{l}\text { Numb. of cases } \\
\text { tested }\end{array}$ & 106 & 162 & 268 \\
\hline & $\leq \times 20$ & 26.2 & 11.1 & 17.0 \\
\hline & $\times \quad 40 \sim 120$ & 26.2 & 29.0 & 27.9 \\
\hline & $\times 160 \sim 240$ & 16.5 & 20.4 & 18.9 \\
\hline & $\times 320 \sim 960$ & 27.3 & 35.8 & 32.5 \\
\hline & $\geq \times 1280$ & 3.8 & 3.7 & 3.7 \\
\hline
\end{tabular}

しかし乍ら，流行中期又は流行後のいずれか の血清で 320単位以上の A S O価を示した小児は 295名中 139名， $47.1 \%$ と明らかに流行前より高 率であつた。

\section{T 12型凝集素価の変動}

流行前血清に和村年令別 T 12型凝集素保有率
Fig. 3 T12 agglutinin titer and ASO titer in scarlet fever, exanthematous disease and T12 H.S. non-manifested cases

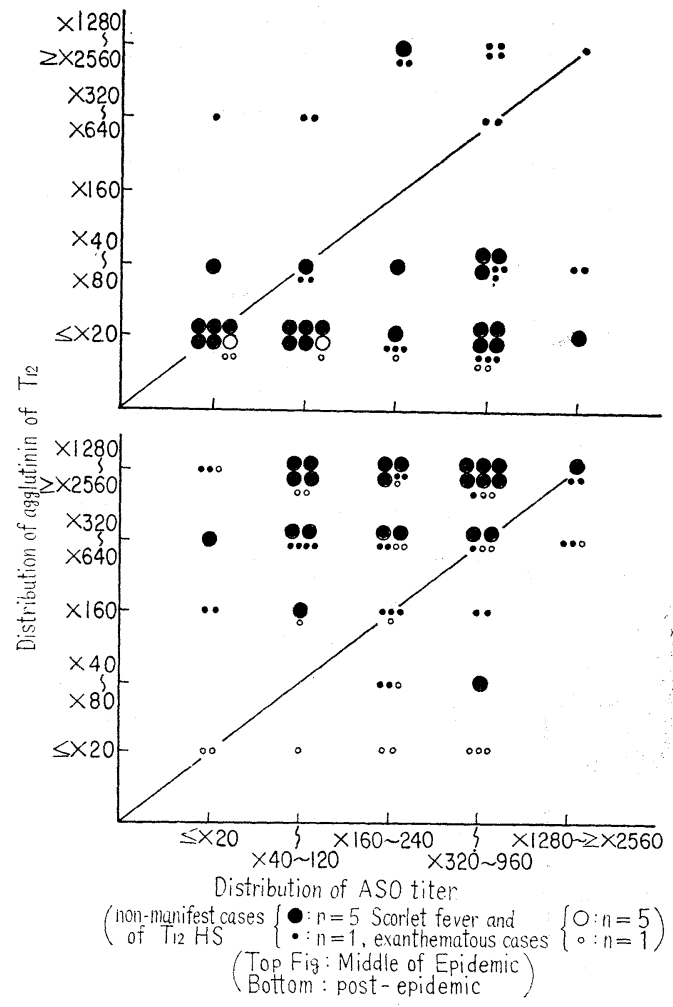

Fig. 4 Agglutinin possessing rate to $\mathrm{T} 12$ and distribution of agglutinin titer during non-epidemic period (1971) in Tsunodate town.

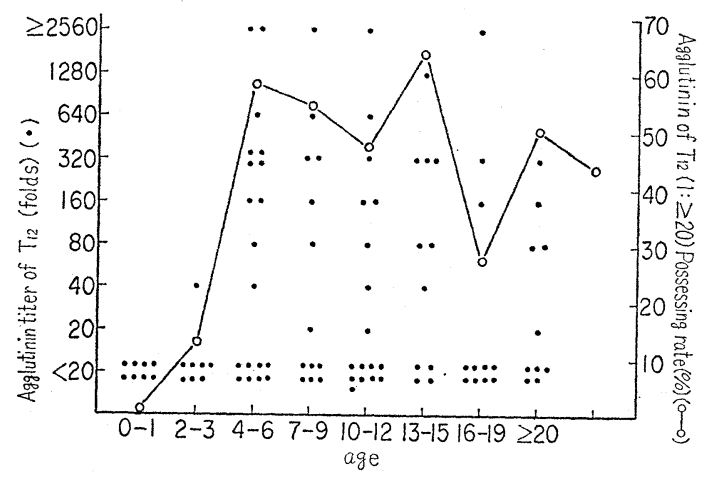

（T12型凝集素価 $1 ： \geq 20 ）$ 及び幾何平均凝集素 価は図 4 に示す如くであつた. 即ち，4〜6才群 に至つて保有率が約58\%及び凝集素価が28.2倍と 急上昇し，溶連菌の伝播がこの年令層の前後から 
活発になることが示唆された。

流行中期に和ける T 12型凝集素保有率は45.8\% 及び凝集素価は27.5倍と流行前に比して大差がな く，AＳO価の上昇変動と異なる成績を示した。 このことはT凝集素産生が A S O産生よりも特く れる可能性を示唆しているものと考兄られる.

これに対して, 流行後に抢ける T12型凝集素保 有率は，図5 の如く，80\%に上昇し，また，幾 何平均凝集素価も365倍と10倍以上の高值を示し た. 特に，流行中期と流行後の 2 回にわたつて血 清の採取のできた 191名中 124名（64.9\%）に流 行後に招ける $\mathrm{T} 12$ 型凝集素価の有意上昇（上昇比 8 倍以上）が確認された。 又，流行前及び流行中

Fig. 5 T 12型菌猩紅熱流行中期及び流行後の健 康小児における T 12型凝集素価保有分布 $-48 \cdot 10 \sim 49 \cdot 1$, 角舘町流行例一

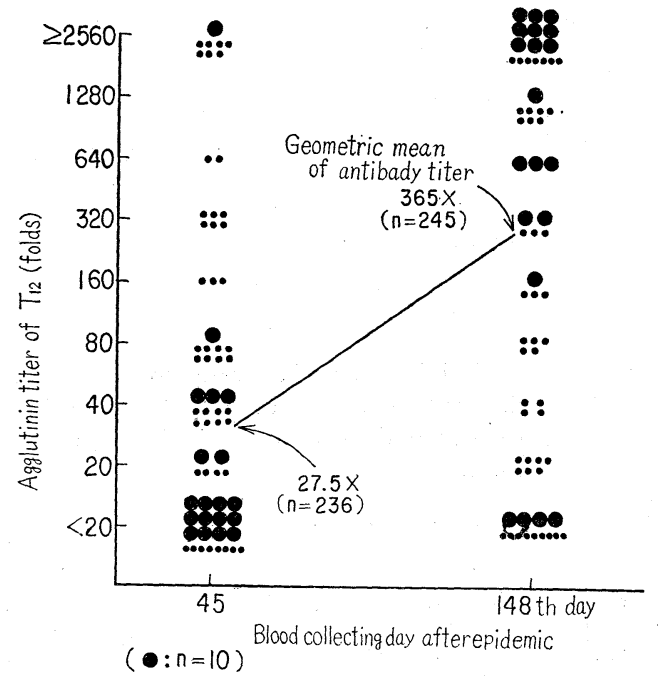

期血清に和いて 1,280倍以上の T 12型凝集素価を 示したものは 7.2１0.5\%にすぎなかつたが，流 行後では46:5\%（245名中 114名）の小児に検出 された。このよらに，流行時に和ける T12型菌の 伝播がこれらの小児間に和いて明らかに高頻度で あつたことが免疫学的に型特異的な $\mathrm{T}$ 凝集素指標 によつて確認された。

3. T 12型菌の侵襲率（感染率）の推計 25名の猩紅熱患者之13名の発疹症患者（その後 の検査で T 12型菌感染症と推定）の発生した両办
稚園児母集団に打ける T 12型菌の侵襲規模を表 4 に示寸如き $\mathrm{T}$ 凝集素価, 顕性感染者及び $\mathrm{T} 12$ 型保 菌者の指標によつて推計した結果, 約 3 力月間の 流行期間に和いて母集団の72.8\%（331名中 241 名）が，更に又，判定保留とした46名を除外す ると，84.6\%（285名中 241名）が T 12型菌に感 染したことが推計された。しかしこの推計值 には（1）対血清又は単一血清の T 12型凝集素価が 1,280倍以上（対血清では非有意上昇）のもの 或いは，(2)単一血清の T 12型凝集素価が 320 640倍のものも一応感染又はその疑いとして加算 されているが，流行前の T 12型凝集素価分布（図 4) に示した如く，これらの中には本流行時以前 の感染の結果によるものも当然含まれていること も考慮されねばならない。しかし作ら，仮にこれ らの血清（T12型保菌者を除く53名）の凝集素価 が本流行時に和ける感染の結果によるるのではな かつたとして除外しても，66.0\%（285名中 188 名) の侵襲率 (感染率) と算出され，従つて，侵 襲率は66.0〜84.6\%の範囲と推計された.

この推計内容を指標別にみてみると, 感染者 の78.7\%（188名中 T凝集素価で血清学的に判 定された顕性感染者18名を含生 148名) 86.7 \%（241名中同上顕性感染者を含む 209名）が T 12型凝集素指標のみによつてその感染が決定又は 推定された。 これに対して, 保菌者を指標とし た場合には感染者の $21.6 \%$ （241名中52名） 27.7 \%（188名中52名）しか決定出来ず， $\mathrm{T}$ 凝集素指 標に比し明らかに低率であつた。これに顕性感染 者指標を加算しても，33.2\%（241名中80名）～ 42.6\%（188名中80名）にすぎず，T凝集素指標 の有用性が確認された。な和，AＳＯは型特異性 がないので推計指標として採用しなかつた。

いずれにしろ，これらの感染者の中から上述の 38名の顕性感染者が発生したわけであるから， 本流行例に和ける T 12型菌の顕性感染率は15.8\% （241名中38名）～202\%（188名中38名）と推 計された。

換言すれば，不顕性感染率は79.8\%〜84.2\%と 算出された。 
Table 4. Estimation of contamination rate of T12 HS in the Institutes prevailed by scarlet fever epidemic due to T12 HS (Tsunodate town in Akita Pref., 1973)

\begin{tabular}{|c|c|c|c|c|c|c|c|c|c|c|}
\hline \multirow{2}{*}{\multicolumn{2}{|c|}{$\begin{array}{l}\text { Institute } \\
\text { Indication factors of } \mathrm{T} 12 \\
\text { HS infection in epidemic period }\end{array}$}} & \multicolumn{3}{|c|}{ Tsunodate kindergarten } & \multicolumn{3}{|c|}{ Tsunodate nursery school } & \multicolumn{3}{|c|}{ Total } \\
\hline & & \multicolumn{2}{|c|}{$\begin{array}{l}\text { number of } \\
\text { cases }\end{array}$} & $\%$ & \multicolumn{2}{|c|}{$\begin{array}{l}\text { number of } \\
\text { cases }\end{array}$} & $\%$ & \multicolumn{2}{|c|}{$\begin{array}{l}\text { number of } \\
\text { cases }\end{array}$} & $\%$ \\
\hline \multirow{4}{*}{$\begin{array}{l}\text { determ- } \\
\text { ined }\end{array}$} & $\begin{array}{l}\text { 1) titer in paired sera } \\
\geqq 8 \times\end{array}$ & $\begin{array}{c}42 \\
(13)\end{array}$ & \multirow{4}{*}{$\begin{array}{c}67 \\
(23)\end{array}$} & \multirow{4}{*}{58.8} & $\begin{array}{c}82 \\
(13) \\
\end{array}$ & \multirow{4}{*}{$\begin{array}{l}141 \\
(26)\end{array}$} & \multirow{4}{*}{65.0} & $\begin{array}{l}124 \\
(26) \\
\end{array}$ & \multirow{4}{*}{$\begin{array}{l}208 \\
(49)\end{array}$} & \multirow{4}{*}{62.8} \\
\hline & 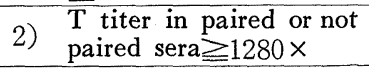 & $\left(\begin{array}{l}9 \\
0\end{array}\right)$ & & & $\begin{array}{c}37 \\
(3) \\
\end{array}$ & & & $\begin{array}{c}46 \\
(3) \\
\end{array}$ & & \\
\hline & 3) scarlet fever patient & $\left(\begin{array}{c}10 \\
4\end{array}\right)$ & & & $\begin{array}{c}15 \\
(3)\end{array}$ & & & $\left(\begin{array}{c}25 \\
(7)\end{array}\right.$ & & \\
\hline & $\begin{array}{l}\text { Harboring case of T12 } \\
\text { HS other than }{ }^{1 / 2) 3)}\end{array}$ & $\begin{array}{l}6 \\
(6) \\
\end{array}$ & & & $\begin{array}{l}7 \\
(7) \\
\end{array}$ & & & $\begin{array}{c}13 \\
(13) \\
\end{array}$ & & \\
\hline \multirow{3}{*}{$\begin{array}{l}\text { estima- } \\
\text { ted }\end{array}$} & 1) $\begin{array}{l}\mathrm{T} \text { titer in paired sera } \\
\geqq 4\end{array}$ & 1 & \multirow{3}{*}{6} & \multirow{3}{*}{5.3} & 4 & \multirow{3}{*}{$\begin{array}{c}27 \\
(3)\end{array}$} & \multirow{3}{*}{12.4} & 5 & \multirow{3}{*}{$\begin{array}{c}33 \\
(3)\end{array}$} & \multirow{3}{*}{10.0} \\
\hline & $\begin{array}{l}\text { 2) } \begin{array}{l}\text { Single serum } T \text { titer } \\
320 \times \sim 640 \times\end{array} \\
\end{array}$ & 5 & & & 10 & & & 15 & & \\
\hline & $\begin{array}{l}\text { cases diagnosed as exa- } \\
\text { nthematous disease }\end{array}$ & $\left.\begin{array}{l}0 \\
0\end{array}\right)$ & & & $\left(\begin{array}{c}13 \\
3\end{array}\right)$ & & & $\left(\begin{array}{c}13 \\
3\end{array}\right)$ & & \\
\hline denied & $\begin{array}{l}\mathrm{T} \text { titer in paired sera or } \\
\text { post epidemic sera } \leqq 20 \times\end{array}$ & & & 19.3 & 2 & & 10.1 & 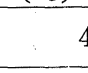 & & 13.3 \\
\hline \multirow{3}{*}{$\begin{array}{l}\text { undete- } \\
\text { rmined }\end{array}$} & $\begin{array}{l}\text { 1) } \text { titer amidst epidemic } \\
\leqq 8 \times \text {, post epidemiic } \\
\text { sera missed }\end{array}$ & 16 & \multirow{3}{*}{19} & \multirow{3}{*}{16.7} & 25 & \multirow{3}{*}{27} & \multirow{3}{*}{12.4} & 41 & \multirow{3}{*}{46} & \multirow{3}{*}{13.9} \\
\hline & $\begin{array}{l}\text { B) Both T titer in paired } \\
\text { sera } 40 \times \sim 80 \times\end{array}$ & 3 & & & 1 & & & 4 & & \\
\hline & 3) $\mathrm{T}$ titer not measured & 0 & & & 1 & & & 1 & & \\
\hline \multicolumn{2}{|r|}{ Total } & \multicolumn{2}{|c|}{$\begin{array}{r}114 \\
(23) \\
\end{array}$} & 100.0 & \multicolumn{2}{|c|}{$\begin{array}{l}217 \\
(29)\end{array}$} & 100.0 & \multicolumn{2}{|c|}{331} & 100.0 \\
\hline
\end{tabular}

( ) : The number of $\mathrm{T} 12$ carrier cases

\section{考察}

我々は昭和 47 年から県内 2 地区に和けるA 群溶 連菌の動態を観察5) してきたが，T12型菌の検出 頻度は47年後半より高くなつてきた。しかし，こ れらの T 12型菌はエリスロマイシン感受性菌であ り，本流行時に検出した $\mathrm{T} 12$ 型菌の薬剤感受性之 相違していた。47年から48年にかけて東京や大阪 にエリスロマイシン耐性の T 12型菌による猩紅熱 の流行例や散発例が報告(6)7)8 されているが，本流 行例の T 12型菌もこれに由来する可能性が高い.

このような猩紅熱の流行に際して, 従来, 保菌 検査や A S O検査等を主とした疫学調査が行なわ れてきたが，母集団に和ける流行菌の動態或いは 侵襲像の解析が満足されてきたとはいいがたい. 最近, 小山は $\mathrm{A}$ 群溶連菌 $\mathrm{T}$ 抗体の疫学的意義につ いて 報告4) したが，我々も，このような観点か ら，A群溶連菌の感染時に産出されると考觉られ る型特異的な $\mathrm{T}$ 凝集素の検出方法及びその意義に ついて検討2)してきた.
まず，本流行時に和ける猩紅熱患者の T 12 型凝 集素産生についてであるが，既報 ${ }^{122)}$ の如く，効 果的な抗生物質投与が行なわれた場合には T凝集 素産生がわるかつたが，然らざる場合には明膫な T凝集素価の有意上昇が観察された。換言すれ ば，不顕性感染者の場合には，抗生剂が投与され ていないが故に，T凝集素産生が行なわれる可能 性が示された。 そこで次に，流行中期に T12型菌 を保菌していた不顕性感染者で，流行中期と流行 後の 2 回にわたつて血清の採取ができた小児26例 について検討した結果, 全例に流行後血清に打け る，T12型凝集素価の有意上昇が確認され，疫学 的指標としてのT凝集素の有用性が示唆された.

このことから，我々は得られた対血清及び単一血 清についてT12型凝集素価を測定し，この結果と 顕性感染者数及び保菌者数を加算して上述の 66.0 〜 $84.6 \%$ という侵襲率 (感染率) の推計值を得た わけである.しかも，これらの感染者の78.7〜 $86.7 \%$ T 12 型凝集素指標のみによつて判定する 
ことができたことは，少なくとも T12型凝集素の 場合, 疫学的指標としての価值が高いということ を示したものと考党られる。 T凝集素は，A S O などとは異なつて，型特異性を有しているので， も乙他の $\mathrm{T}$ 型についても特異的な $\mathrm{T}$ 凝集素を検出 測定することができれば，A群溶連菌の疫学像は より詳細になるものと考觉られる。健康保菌者に ついてこれ迄に得られた成績では，T4型菌な どでは保菌後明瞭な T凝集素産生が認められてい る.しかし，B3264型の如く，その産生が必らず しも良好でない場合も観察されているので，これ らの点も含めて, 今後更に $\mathrm{T}$ 凝集素の意義を検討 していく考穵でる.

\section{結 論}

昭和48年10〜12月, 秋田県角館町で E M と T C に耐性の T 12型菌による猩紅熱が流行した. 我々 は，猩紅熱の多発した 2 幼稚園児を対象として $\mathrm{T} 12$ 型菌の血清疫学調査一 T 12型凝集素価及び A S O価測定一を試み, 次の結果を得た。

(1)，流行中期又は流行後のいずれかの時期で 320 単位以上の A S O価を示したものが $47.1 \%$ に 検出され, 流行前に比較して, 明らかに高值に変 動していた。

（2），流行前の年令別 T 12型凝集素保有率及び 幾何平均凝集素価は 4〜6才群(58\%，28.2倍)に いたつて急上昇し,感染頻度の上昇が示唆された。

（3），流行中期血清の T 12型凝集素保有率及び 凝集価は流行前と有意差でなかつたが，流行後血 清では $80 \%$ 及び 365倍と明らかに上昇し，特に， 対血清の採取できた 191名中 124名 $(64.9 \%)$ に T 12型凝集素価の有意上昇が認められた.
（4），T 12型凝集素価，顕性感染者及び T 12型 保菌者を T 12 型の感染指標として，幼稚園児母集 団にかける侵襲率（感染率）を推計した結果， 66.0〜 84.6\%の推計值が得られた. 特に, この内 の78.7〜86.7\%は T 12型凝集素指標の又によつて 判定可能であり, $\mathrm{T}$ 凝集素指標の疫学的価值が確 認された。

(5), 不顕性感染率は79.8 84.2\% と推計され た。

\section{文献}

1）森田盛大，金鉄三郎，高山和子，藤宮芳章，柴 田芳実, 白取剛彦, 須藤恒久, 石田名香雄 : 昭 和48年角舘町に発生した猩紅熱について。秋田 県衛生科学研究所報, 17 (印刷中), 1973.

2）森田盛大，金鉄三郎，高山和子，藤宮芳章, 柴 田芳実, 白取剛彦, 須藤恒久, 石田名香雄: A 群溶連菌感染時に打ける丁凝集素産生につい て.第28回日本細菌学会東北支部会口演, 1974.

3) 宮本 泰：レンサ球菌一 $\mathrm{A}$ 群レンサ球菌の㠜 集反応飞上る 型別法, 臨床検査, $13: 1085$ 1091, 1969.

4) 小山実: 人血清中の $\mathrm{A}$ 群溶連菌 T抗体の疫 学的意義化関する研究. 感染症学雑誌, $47: 195$ $-203,1973$.

5）白取剛彦, 森田盛大, 茂木武男, 金鉄三郎 : 猩 紅熱汇関寸る疫学的研究. 感染症学雑誌, 47 : 510-513, 1973.

6) 斎藤 譲, 宮本 泰 : 立川市内一幼稚園に拈け る溶連菌の保菌状態について. 第48回日本伝染 病学会抄録集, $10,1974$.

7) 田中 英, 山口 剛, 佐藤磨人, 中沢 進, 佐 藤肇：小児科領域の咽頭より分離した $\mathrm{A}$ 群溶 連菌の耐性パターン.第48回日本伝染病学会抄 録集, $11,1974$.

8）足立利幸, 新美裕成, 中島邦夫, 杉山茂彦：昭 和 48 年度, 桃山病院入院の猩紅熱患者及び学童 の咽頭溶連菌の菌型と薬凨感受性について. 第 48回日本伝染病学会抄録集, $11,1974$. 
A Seroepidemiological Study on Type T-12 Group A Streptococcus which Caused

An Epidemic of Scarlet Fever in 1973

Morihiro MORITA, Tetsusaburo KON, Kazuko TAKAYAMA, Yoshiaki FUJIMIYA and Yoshimi SHIBATA

Department of Microbiology, Akita Prefectural Institute of Public Health

Takehiko SHIRATORI

Department of Microbiology, Miyagi Prefectural Institute of Public Health

Tsunehisa suto

Department of Microbiology, Akita University School of Medicine

Nakao ISHIDA

Department of Bacteriology, Tohoku University School of Medicine .

An epidemic of scarlet fever caused by type T-12 group A streptococcus which showed no sensitivity to erythromycine and tetracycline occured in Kakunodate, Akita Prefecture, from October to December in 1973. The morbidity of scarlet fever was 279.5 per 100,000 of population and $85 \%$ of patients were children 3 to 6 years o1d. Sera obtained from 331 children in two kidergartens, of which 38 children developed scarlet fever, in the middle of and after the epidemic and sera from 100 healthy inhabitants in this district in 1971 were examined for a seroepidemiological survey on type T-12 group A streptococcus. The obtained results were as follows.

1. Before the epidemic, the geometric mean ASLO titer of sera collected from children 4 to 6 years old was 1 : 33.8 and the highest ASLO titer was observed in age group 10 to 12 years of old. ASLO titers of sera from children 3 to 6 years of age in the middle of the epidemic apparently increased higher than those of sera from children 4 to 6 years old before the epidemic. Particularly, ASLO titers of $1: \geq 320$ were observed in $47.1 \%$ of children whose sera were collected either in the middle of or after the epidemic, as compared with $6 \%$ in sera obtained before the epidemic.

2. Eleven $(57.9 \%)$ out of 19 children 4 to 6 years old before the epidemic revealed $\mathrm{T}$ agglutinin titers of $1: \geq 20$ against type T-12 group A streptococcus and the geometric mean titer was $1: 28.2$, whereas $80 \%$ of sera from children in two kindergartens after the epidemic showed the $T$ agglutinin titers $1: \geq 20$ and the geometric mean titer increased remarkably to $1: 365$.

3. Significant rises ( $1: Z 8$ ) of $T$ agglutinin titer to the type $T-12$ after the epidemic were detected in 124 (64.9\% ) out of 191 children whose sera were collected both in the middle of and after the epidemic.

4. The rate at which children in two kindergartens were infected with the type T-12 streptococcus was estimated as $66.0-84.6 \%$ on the basis of three indexes of significant rise of the $T$ agglutinin titer, patient with scarlet fever and carrier of the type T-12 streptococcus. About 78.7 to $86.7 \%$ out of the rate were estimated by the index of the $\mathrm{T}$ agglutinin titers. Thus, it may be useful for seroepidemiological surveys on group A streptococci to measure $\mathrm{T}$ agglutinin titers against each type $\mathrm{T}$ streptococcus in human sera.

5. The rate of inapparent infection with the type $\mathrm{T}-12$ group A streptococcus during this epidemic was estimated as $79.8-84.2 \%$. 